\title{
INHIBITION OF RENTN SECRETION BY PLATELET ACTIVATING FACTOR (ACETYLGLYCERYL ETHER PHOSPHORYLCHOLINE) IN CULTURED RAT RENAL JUXTAGLOMERULAR CELLS
}

\author{
Josef Pfeilschjfter, Armin Kurtz and Christian Bauer \\ Physiologisches Institut der Universität Zürich, \\ Winterthurerstrasse 190, $\mathrm{CH}-8057 \mathrm{Zür}$ ich, Switzerland
}

eived February 11, 1985

\begin{abstract}
:etylglyceryl ether phosphorylcholine (AGEPC), commonly known as atelet activating factor, was found to strongly inhibit renin cretion in cultures rich in juxtaglomerular cells. This inhibitory tion of AGEPC was accompanied by an enhanced calcium permeability of ie cell membrane as evaluated from measurements of the uptake of 'Ca. Simultaneous addition of the calcium channel blocker veraamil abolished the effects of AGEPC on both renin secretion and Ilcium permeability. Furthermore, addition of AGEPC to the cell ulures led to a decrease of $32 \mathrm{P}-1$ abeled phosphatidylinositol , 5-bisphosphate and to an increase in ${ }^{3} \mathrm{H}-1$ abeled diacylglycerol, ndicating an activation of phospholipase C by AGEPC. $\odot 1985$ Academic Press, Inc.
\end{abstract}

atelet activating factor (PAF) was first described as an inductor of atelet aggregation during Igf-mediated anaphylaxis in the rabbit ,2). PAF has recently been identified as 1-0-alkyl-2-acetyl-sn-glyce,-3-phosphorylcholine (AGRPC) (3). This phospholipid causes marked vaconstriction and increased permeabjlity of blood vessels (4) as well ; contraction of ileal smooth muscle (5). AGEPC is produced from basoil is on immunological challenges and from platelets, neutrophils and icrophages in response to specific stimuli (6-11) and has also been zmonstrated in the venous effluent of isolated perfused rat kidney 12) and also in isolated glomeruli (28). Authors in (13) have shown lat AGEPC possesses marked antihypertensive activity when given to soldblatt" one-kidney, one-clip hypertensive rats. Hypertension in this andition is known to be due to increased levels of plasma renin with ubsequent production of angiotensin II. In view of the fact that AGEPC as vasoconstrictive properties and vasoconstrictive agents such as

bhreviations used: AGEPC, acetylglyceryl ether phosphorylcholine: AF, platelet activaling factor: $A I$, angiotensin 1; PIPz, phospha idvinositol 4,5 bisphosphate; DAG, 1,2-diacylglycerol; IPs, nositoitrisphosphate. 
angiotensin $I I$ and arginine-vasopressin markedly inhibit renin secretior (14), it is tempting to speculate that the antihypertensive properties of AGEPC in Goldblatt hypertension might be due to a direct inhibition of renin secretion in the kidney.

Recently we have established a cell culture system from rat kidneys containing about $60 \%$ of juxtaglomerular cells which allows study of renin secretion in some detail. Aim of the present study was to investigate the influence of AGEPC on renin secretion as well as on some pertilent cellular processes like calcium permeability of the cell membrane (15) and phosphoinositide metabolism (16-19).

\section{Laterials and Methods}

itock solutions of AGEPC (Sigma), $\left(10^{-3} M\right)$ in ethanol were prepared and complexed with $0.3 \mathrm{mg} / \mathrm{ml}$ of bovine serum albumin (BSA) in MEM to sive a concentration of $10^{-6} \mathrm{M}$. The BSA bound AGEPC was added to the sells to give a final concentration of $10^{-8} \mathrm{M}$ or $10^{-10} \mathrm{M}$. Carrier ree ${ }^{32} \mathrm{Pi}_{\mathrm{i}},{ }^{45} \mathrm{Ca}$ and $\left({ }^{3} \mathrm{H}\right)$-glycerol were from Amersham international. T.L.C. plates (precoated silicagel 60 with concenration zone, $0,25 \mathrm{~mm}$ thick) came from Merck, Darmstadt, F.R.G. Lipid t tandards and BSA (essentially fatty acid-free) were obtained from igma. Cell culture dishes and cell culture media were from Greiner, lürtingen, F.R.G. and Boehringer-Mannheim, respectively.

ell_ Cultures rich in juxtaglomerular cells were prepared as described reviously (15). In brief, rat kidneys were perfused in situ with Hank's alanced salt solution supplemented with 1 g glucose, 12.11 g sucrose, $, 2 \mathrm{~g} \mathrm{NaHCO}, 2.6 \mathrm{mM}$ glutamine, $0,84 \mathrm{~g} \mathrm{Na-citrate} \mathrm{and} 10 \mathrm{mg} \mathrm{BSA}$ per iter. Cortical pieces (1 $\mathrm{mm}^{3}$ ) were incubated with this buffer, conaining $0,25 \%$ trypsin and $0,1 \%$ collagenase instead of $\mathrm{Na}-\mathrm{citrate}$. The uspension was gassed with $5 \% \mathrm{CO}_{2}$ in air and stirred with a magneic bar at $37^{\circ} \mathrm{C}$. After $120 \mathrm{~min}$. the solution was poured over a 0,22 $m$ sieve. Cells passing the sieve were washed two times with culture edium (RPMI $1640,25 \mathrm{mM}$ Hepes, $0,66 \mathrm{U} / \mathrm{ml}$ insulin, $100 \mu \mathrm{m} / \mathrm{ml}$ streptomyin, $100 \mathrm{U} / \mathrm{m} 1$ penicillin and $10 \%$ fetal bovine serum and seeded in tisue culture dishes at a density of $10^{5}$ cells $/ \mathrm{cm}^{2}$. Cultures were ept at $37^{\circ} \mathrm{C}$ in a humidified atmosphere at $5 \% \mathrm{CO}_{2}$ in air. After No days of culture, $60 \%$ of the adherent cells displayed a strong nmunoreactivity for a specific antibody against renin. The renin conant of the cultured cells was about $l \mu \mathrm{g} A T / h \times 10^{6}$ cells at that ime.

atermination of Renin Secretion. Renin activity was determined by s ability to generate angiotensin I (AT) from the plasma of bilateily nephrectomized rats exactly as described in $(20)$. AI was determiad by radioimmunossay (TDW, Dreieich, F.R.G.) Renin secretion was ivestigated at the second day of culture. The culture medium was substuted by a prewarmed buffer consisting of $132 \mathrm{mM}$ NaCl, $5 \mathrm{mM} K \mathrm{KC}, 0,8 \mathrm{mM}$ $\mathrm{SO}_{4}, 2 \mathrm{mM} \mathrm{CaCl}, 10 \mathrm{mM} \mathrm{Na}$-acetate, $2 \mathrm{mM} \mathrm{NaH}_{2} \mathrm{PO}_{4}, 10 \mathrm{mM}$

ucose, $20 \mathrm{mM}$ hepes $(\mathrm{pH}=7,3)$ and the culture dishes were placed on a ating block at a temperature of $37 \% \mathrm{c}$. The renin secretion rate s calculated from the linear increase of the renin activity of the 11 -conditioned buffer.

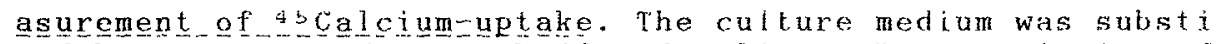
ted by a prewarmed Hepes buffered saline thBs) consisting of $20 \mathrm{mM}$ He- 
pes, $148 \mathrm{mM} \mathrm{NaCl}, 5 \mathrm{mM} \mathrm{KCl,} \mathrm{2mM} \mathrm{CaCl2,} \mathrm{1mM} \mathrm{MgCl2,} \mathrm{6mM} \mathrm{Glucose,}$ $\mathrm{pH} 7,3$ supplemented with $45 \mathrm{Ca}(4 \mu \mathrm{Ci} / \mathrm{ml})$. Simultaneously, AGEPC or verapamil or a combination of both was added. At different times, buffer was withdrawn and the cells quickly washed with $10 \times 1 \mathrm{ml}$ ice-cold HBS containing $10 \mathrm{mM} \mathrm{CaCl}$. The cells were lysed by the addition of $1 \mathrm{ml}$ of $0,5 \mathrm{~N} \mathrm{NaOH}$ and the radioactivity was counted in $10 \mathrm{ml}$ Aquasol 2 (New England Nuclear) in a B-scintillation counter.

Prelabeling of cells_with $32 \mathrm{Pi}$ and (3H)-glycerol. After

two days of culture, medium was removed and the cells were incubated

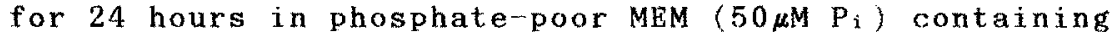
$100 \mu \mathrm{Ci} / \mathrm{ml} 32 \mathrm{Pi}$ or with $\mathrm{MEM}$ containing $5 \mu \mathrm{Ci} / \mathrm{ml}$ ( $\left.{ }^{3} \mathrm{H}\right)-$ glycerol. After this prelabeling period the medium was replaced by fresh medium either without (control) or with AGEPC (10-8M).

Extraction, separation and guantitation of Phosphoinositides and piacylglycerol. Incubations were terminated by addition of ice-cold methanol-chloroform, and lipid extraction was done as described (21). The extracted $32 \mathrm{p}-1$ abeled phospholipids were separated on thinlayer plates impregnated with potassium oxalate and EDTA with a solvent system consisting of chloroform/methanol/4N $\mathrm{NH}_{4} \mathrm{OH}(45 / 35 / 10$, by vol.) Neutral lipids were separated using n-heptane/ diethyl ether/acetic acid $(75 / 25 / 4$, by vol.) as described (21). Phospholipids and neutral lipids were localized by comigration of standards followed by iodine staining and 32 p-labelled lipids additionally by autoradiography. The spots were scraped from the chromatographs and counted by liquid scintillation in water (Cerenkov counting) for $32 \mathrm{p}$ labelled lipids. ( $\left.{ }^{3} \mathrm{H}\right)-1$ abeled 1 ipids were analysed with a TLC-linear analyzer LB 2821 from Berthold, München, F.R.G. The detection efficiency for ( 3 H) was about $1 \%$. Protein determination was done according to the method of Lowry (22) with BSA as standard.

\section{Results}

Fig. I shows that AGEPC strongly inhibited the spontaneous renin secretion in a concentration dependent manner. Whilst in control experiments, the rate of renin secretion was about $390 \mathrm{pg}$ AI/h per min per dish, AGEPC at concentrations of $\left(10^{-10} \mathrm{M}\right)$ and $\left(10^{-8} \mathrm{M}\right)$ reduced the secretion rate to $175 \mathrm{pg}$ AT/h and to $72.5 \mathrm{pg}$ Al/h per min. and dish respectively. Note, that the term Al/h is formally equivalent with one unit of renin activity. This inhibition could only be observed during the first 15 minutes and reached control levels after 60 minutes. Simultaneous addition of verapamil $\left(10^{-5} \mathrm{M}\right)$ completely abolished the inhibitory effect of AGEPC, whilst the addition of verapamil alone greatly enhanced renin secretion (Fig. 1).

Fig. 2 shows that calcium uptake by the cuitured cells was increased in the presence of $\mathrm{AGEPC}\left(10^{-8 M}\right)$. Verapamil $\left(10^{-5} \mathrm{M}\right)$

strongly reduced the calcium uptake and the simultaneous addition of AGEFC and verapamil also reduced the calcium uptake, but to a slighter degree than did verapamil alone. 


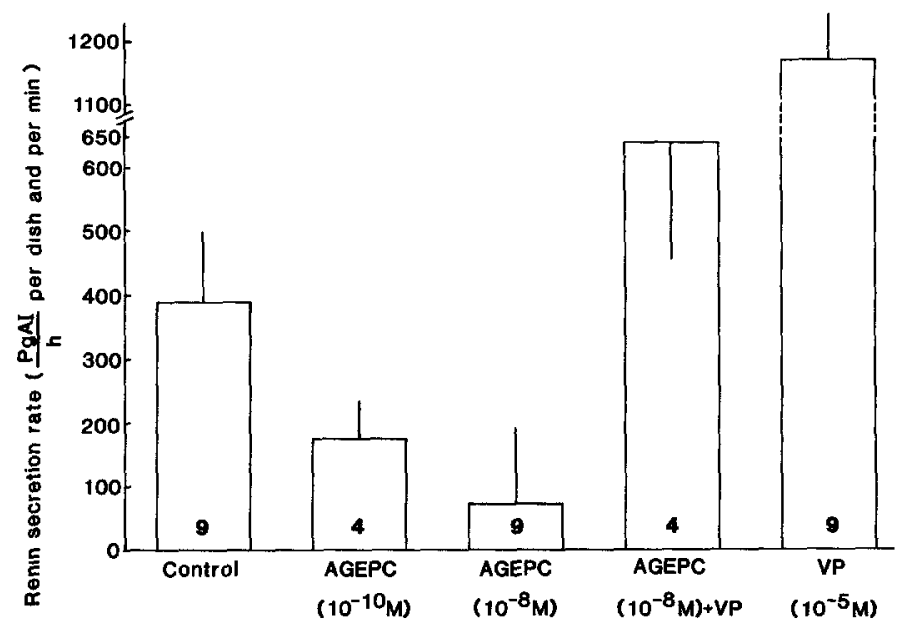

Fig. 1

Renin secretion rate of cultured juxtaglomerular cells in the presence of acetylglyceryl ether phosphorylcholine (AGEPC) $\left(10^{-8} M\right)$ and $\left(10^{-10} M\right)$, verapamil (VP)

$\left(10^{-5} \mathrm{M}\right)$ and the combination of AGEPC $\left(10^{-8} \mathrm{M}\right)$ and VP $\left(10^{-5} \mathrm{M}\right)$. Data are mean $+/-$ S.E.M. Figures at the bottom of the columns indicate the number of independent experiments.

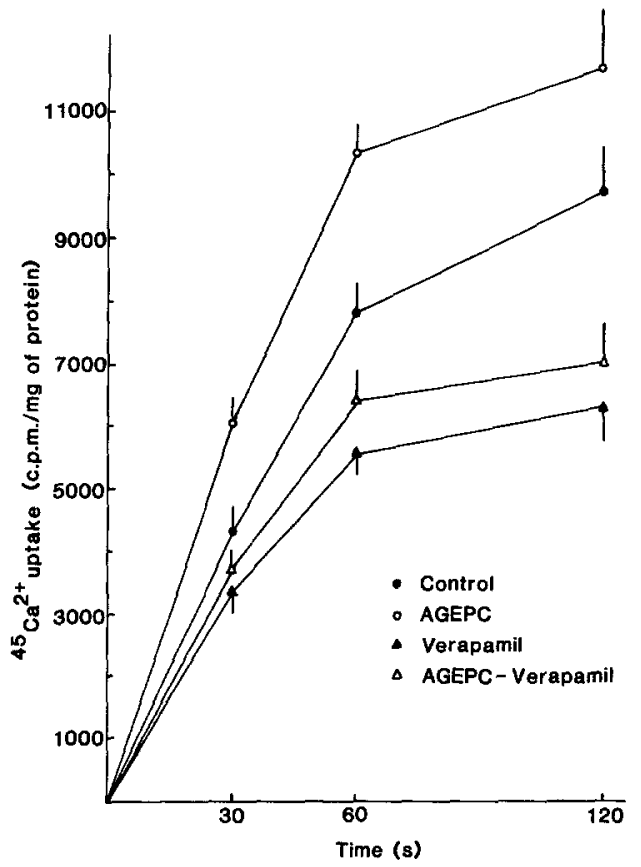

F1g. 2

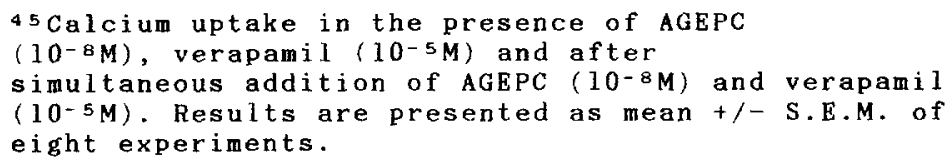




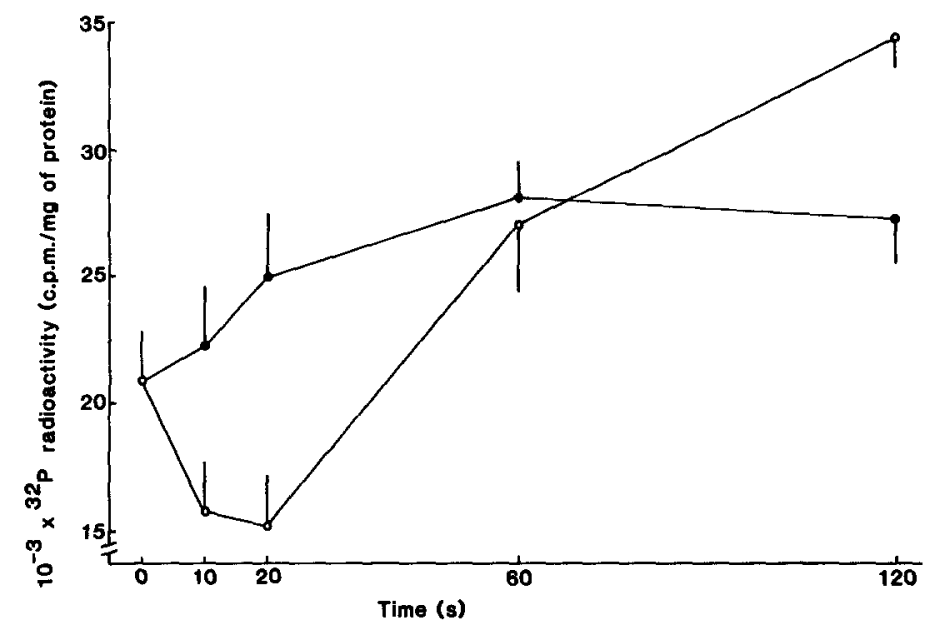

Fig. 3

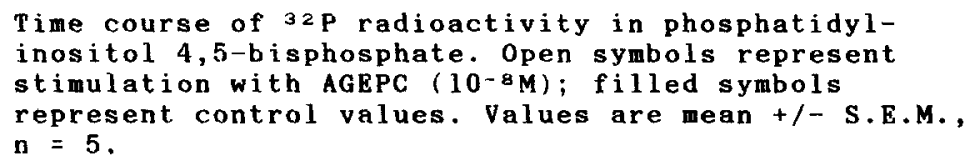

lition of $A G E P C\left(10^{-8} M\right)$ to the cells provoked a rapid decrease of

P) radioactivity found in phosphatidylinositol 4,5-bisphosphate

$\left[\mathrm{P}_{2}\right)$ (Fig. 3). This effect could be detected as early as 10 se-

lds after addition of AGEPC and was maximal (60\% of control) within 20

One minute after addition of AGEPC, the level of $32 \mathrm{P}$ in PIP2

areased and approached control levels, followed by an increase above

itial levels at 2 minutes. This early decrease of $32 \mathrm{p}-1$ abel in

$\mathrm{P}_{2}$ was followed by a subsequent increase of $\left({ }^{3} \mathrm{H}\right)-\mathrm{glyce}$

1-label in diacylglycerol (DAG) which had a maximum 30 s after addion of AGEPC (Fig, 4).

\section{scussion}

e strong inhibition of renin secretion by AGEPC (Fig. 1) is comparable that of other vasoconstrictive agents like angiotensin II and argini- vasopressin (14). In analogy to what we have recently shown for giotensin II, AGEPC inhibits renin secretion probably by enhancing the -. permeability of the cell membrane, thereby increasing the intracelluir calcium concentrations (15). The complete suppression by verapamil

- the action of $A C E P C$ on renin secretion suggests that $A G E P C$ acts by rening calcium channels. The fact that an inhibition of renin secretion suld be observed only during the first 15 min. after addition of AGEPC 


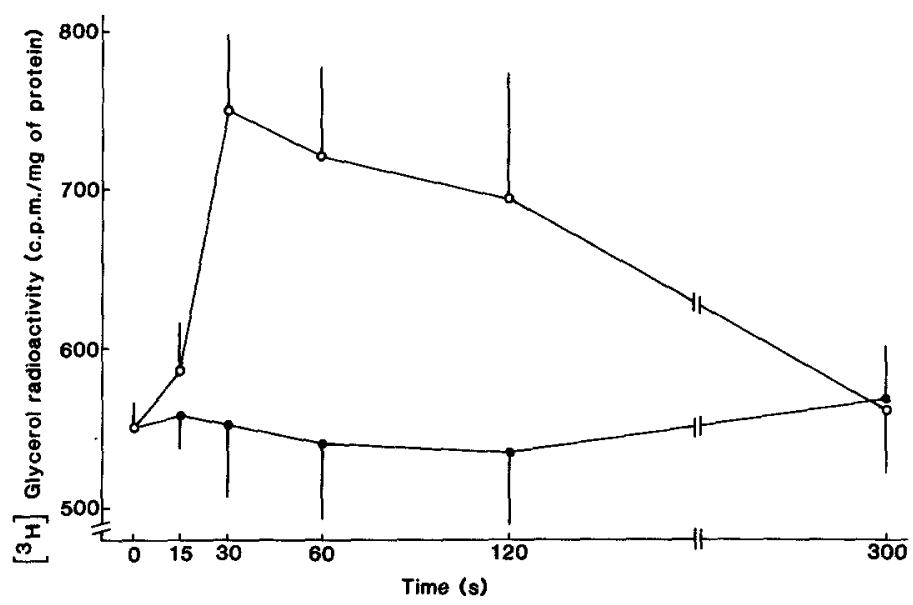

Fig. 4 Time course of $\left({ }^{3} H\right)$ glycerol radioactivity in l,2-diacylglycerol in juxtaglomerular cells stimulated with AGEPC $\left(10^{-8} \mathrm{M}\right)$; open symbols represent stimulation with AGEPC $\left(10^{-8}\right)$; filled symbols represent control values.

s very likely to be due to the fast degradation of the agent (23).

$t$ now appears to be generally accepted that hormones and neurotransmiters that use calcium as second messenger specifically hydrolyse membrae phosphoinositides. Michel1 suggested in 1975 that calcium mobiliza-ion is linked to phosphatidylinositol breakdown (24). However, more ecent experiments have demonstrated that the primary event in receptor timulated inositol phospholipid metabolism is by an action of hospholipase C (PIC) upon phosphatidylinositol 4,5-bisphosphate $\mathrm{PIP}_{2}$ ) (for review see 25-26). Since AGEPC is known to cause I $\mathrm{P}_{2}$ degradation in platelets (17-19) and hepatocytes (16), we have samined the eftect of AGEPC on PIP2 metabolism in our cell culture istem. The results presented in Figs. 3 and 4 clearly show that AGEPC sads to a loss of radioactivity from PIP2 and an increase of H)-glycerol label in diacylglycerol (DAG). Therefore, AGEPC parently stimulates PLC in our cell culture system. We have observed :ry similar effects of angiotensin II and arginine-vasopressin on the lositol phospholipid metabolism in these cells (manuscript submitted). ith of the cleavage products of PIP2 metabolism, i.e. DAG and ositol 1,4,5-trisphosphate (IP3) are important second messergers or review see (27)). IP3 is thought to be the intracellular sig1 to promote hormone induced calcium mobilization and DAG activates otein kinase $G$ which in turn phosphorylates various cellular proteins. have recently found that the phorbol ester, 12-0-tetradecanoyl-- 
bol-13-acetate, which is widely used as an activator of protein ki-

C, enhances the calcium permeability in cultured glomerular mesancells (unpublished results). In view of this, it can be speculated an activation of protein kinase $C$ by $D A G$ is causally related to the ease in calcium permeability observed in the present experiments (2).

ihis report we have presented evidence, that AGEPC strongly influenrenin secretion and phosphoinositide metabolism in cultures rich in al juxtaglomerular cells. The low concentration at which AGEPC inhi3 renin secretion $\left(10^{-10} \mathrm{M}\right)$ and also the fact that AGEPC is proed by the kidney itself $(12,28)$ supports the notion that AGEPC is olved in the regulation of kidney renin secretion and may be part an intrarenal feedback mechanism controlling renin secretion.

\section{nowledgements}

excellent technical assistance of Mrs. R. Ludwig is gratefully nowledged. We furthermore thank Mrs. 0. Stoupa for her secretarial istance and Mr. W. Gehret for doing the art work.

\section{erences}

Siraganian, R.P., Osler, A.G. (1971) J. Immunol. 106, 1244-1251. Benveniste, J., Henson, P.M., Cochrane, C.G.

(1972) J. Exp. Med. 136, 1356-1377.

Hanahan, D.J., Demopoulos, C.A., Liehr, J., Pinckard, R.N.

(1980) J. Biol. Chem. 255, 5514-5516.

Humphrey, D.M., McManus, L.M., Satouchi, K., Hanahan, D.J.,

Pinckard, R.N. (1982) Lab. Invest. 46, 422-427

Findlay, S.R., Lichtenstein, L.M., Hanahan, D.J., Pinckard, R.N.

(1981) Am. J. Physiol. 241, C130-Cl33

Camussi, G., Mencia-Huerta, J.M., Benveniste, J.

(1977) Immunology 33, 523-534

, Mencia-Huerta, J.M., Benveniste, J.

(1979) Eur. J. Immunol. 9, 409-415

1 Lynch, J.M., Lotner, G.Z., Betz, S.J., Henson, P.M.

(1979) J. Immunol. 123, 1219-1226

) Pinckard, R.N., Farr, R.S., Hanahan, D.J.

(1979) J. Immunol. 123, 1847-1857

3) Lotner, G.Z., Lynch, J.M., Betz, S.J., Henson, P.M.

(1980) J. Immunol. 124, 676-684

1) Clark, P.O., Hanahan, D.J., Pinckard, R.N.

(1980) Biochim. Biophys. Acta 628, 69-75

2) Pirotzky, E., Bidault, J. Burtin, C., Gubler, M.C., Benveniste, J. (1984) Kidney Int. 25, 404-410

3) Blank, M.L., Snyder, F., Byers, L.W., Brooks, B., Muirhead, E.E. (1979) Biochem. Biophys. Res. Commun. 90, 1194-1200

4) Keeton, T.K., Campbel1, W.B.

(1981) Pharmaco1. Rev. 31, 81-227 
(15) Kurtz, A., Pfeilschifter, J., Bauer, C. (1984) Biochem. Biophys. Res. Commun. 124, 359-366

(16) Shukla, S.D., Buxton, D.B., Olson, M.S., Hanahan, D.J. (1983) J. Biol. Chem. 258, 10212-10214

(17) Lapetina, E.G. (1982) J. Biol. Chem. 257, 7314-7317

(18) Shukla, S.D., Hanahan, D.J. (1983) Arch. Biochem. Biophys. 227, 626-629

(19) Mauco, G., Chap, H., Douste-Blazy, L. (1983) FEBS Lett. $153,361-365$

(20) Rightsel, W.A., Okamura, T., Inagami, T., Pit.cock, J.A., Taki, Y., Brooks, B., Brown, P., Muirhead, E. E. (1982) Circ. Res. 50, 822-829

(21) Pfeilschifter, J., Kurtz, A., Bauer, C. (1984) Biochem. J. 223, 855-859

(22) Lowry, O.H., Rosebrough, N.J., Farr, A.L., Randal I, R.J. (195l) J. Biol. Chem. 193, 265-275

23) Blank, M.L., Lee, T., Fitzgerald, V., Snyder, F. (1981) J. Biol. Chem. 256, 175-178

24) Michel1, R.H. (1975) Biochem. Biophys. Acta $415,81-147$

25) Michel1, R.H., Kirk, C.J., Jones, L.M., Nownes, C.P., Greba, J.A. (1981) Phil. Trans. R. Soc. Lond. Biol. Sci. B 296, 123-137

26) Miche11, R.H. (1983) Life Sciences, 32, 2083-2085

27) Berridge, M.J. (1984) Biochem. J. 220, 345-360

28) Pirotzky, E., Ninio, E., Bidault, J., Pfisier, A., Benventste, J. (1984) Lab. Invest. 51, 567-572 